\title{
DEVELOPMENT OF COLD FIBER HEAD SPACE SOLID-PHASE MICROEXTRACTION FOR ANALYSIS OF 2,5 HEXANDION IN URINE
}

\author{
Yasaman Pourbakhshi', Abdul Rahman Bahramy1, ${ }^{\circledR}$, Farshid Ghorbani Shanha1, \\ Mohammad Javad Assari ${ }^{1}$, Leila Tajik ${ }^{1}$, Maryam Farhadian ${ }^{2}$
}

https://doi.org/10.23939/chcht13.04.482

\begin{abstract}
Hexanedione (2,5-HD), the main metabolite of $n$-hexane was extracted from urine samples using cold fiber head space solid-phase microextraction (CF-HS-SPME) based on thermoelectric cooling and analyzed with gas chromatography equipped with a flame ionization detector (GC-FID). Important parameters for improved efficiency of fiber sorption including sample volume, extraction time and temperature were optimized using a central composite design. The optimum conditions were determined, under which the detection limit and the relative standard deviations were found. The method was shown to be rapid, sensitive and easier than conventional methods for quantitative analysis of $2,5-\mathrm{HD}$ in urine samples.
\end{abstract}

Keywords: urine samples, 2,5-hexanedione, cold fiber, solid-phase microextraction, $n$-hexane.

\section{Introduction}

$n$-Hexane is a solvent widely used in industry to make glues, paints, varnishes, and printing inks. Epidemiological human studies and experimental research on animals have shown that exposure to $n$-hexane cause serious impairment of the nervous system and induces peripheral neuropathy in both groups. The 2,5-hexandione (2,5-HD), a basic metabolite of $n$-hexane, has been shown to be responsible for the neurological damage in exposed persons [1-3]. The urinary levels of 2,5-HD have been used to evaluate workers exposed to $n$-hexane. It is also a metabolite of 2-hexanone (methyln-butyl ketone).

The American Conference of Governmental Industrial Hygienists (ACGIH) introduced 2,5-HD as a

\footnotetext{
${ }^{1}$ Center of Excellence for Occupational Health, Research Center of Health Sciences,

School of Public Health, Hamadan University of Medical Sciences, Hamadan, Iran

${ }^{2}$ Department of Biostatistics, School of Public Health, Hamadan University of Medical Sciences, Hamedan, Iran

$\bowtie$ bahrami.abdulrahman@gmail.com

(c) Pourbakhshi Y., Bahramy A., Shanha F., Assari M., Tajik L., Farhadian M., 2019
}

biological exposure index for hexane exposure. The timeweighted average for threshold limit value of hexane is $50 \mathrm{ppm}$ for air exposure and the biological exposure index for urinary $2,5-\mathrm{HD}$ is $0.4 \mathrm{mg} / 1$ at the end of the working shift at the end of the workweek [4].

The analysis of toxicological effect of $n$-hexane is described in the literature by several methods including gas chromatography-mass spectrometry (GC-MS), hydrolysis treatments and analysis by GC with flame ionization detector (GC-FID), high performance liquid chromatography with ultraviolet (HPLC-UV), derivatization of 2,5-HD and analysis by electron capture detector (GC-ECD) of human exposure [5-9]. The most popular preparation methods used are liquid-liquid and solid-phase extraction.

Over the last decade, several methods based on solid phase microextraction are reported in the analysis of pollutants in air and extraction of analytes from urine samples [10-17]. The most developed methods to determine volatile biological indexes in urine samples are static or dynamic headspace and head space-solid phase microextraction (HS-SPME). The static headspace method is based on partition of analytes between gaseous and liquid phases. This method has low contamination, high recoveries and low detection limits. The SPME is simple, rapid, cost-effective, and solvent-free.

Although SPME is a sensitive method it is limited by its selectivity and extraction capability. In HS-SPME, enhancement of sample temperature increases the vapor pressure and improves the mass transfer of the analyte but has the effect of partitioning the coefficient of the analytes-fiber and reducing the extraction capabilities due to the exothermic nature of the adsorption.

The cold fiber SPME (CF-SPME) was recommended by Zhang and Pawliszyn [18] to overcome the exothermic characteristic of analyte sorption by fiber. In CF-SPME the temperature of coating fibers was decreased when sample temperature was increased to improve the extraction. This approach was automated and applied to determine some volatile and semi-volatile compounds in shampoo, cork, soil matrices, sediment samples, air and 
the screening of volatile compounds in tropical fruit [19-24].

Liquid carbon dioxide or nitrogen was used in automation for the cooling of SPME fiber that has a large needle size in its cooling system and causes septa coring and pressure drop in the analysis of samples.

A new thermoelectric cooler (TEC) was introduced to cool the SPME fiber for determination of hexanal, nonanal, and undecanal in rice samples and then applied to determination of BTEX in ambient air $[25,26]$. The cooler can control the fiber temperature, has no moving parts, and it is small, lightweight, easy to move around the laboratory and environmentally safe. To our knowledge there is no similar study based on CF-HS-SPME for sampling and determination of 2,5-HD in the urine samples and there is still a great deal to learn about the applicability of CF-HS-SPME as a monitoring tool in urinary samples. Biological samples are complex compounds and the physicochemical properties of semivolatile compounds (such as 2,5-HD) differ from those in water, soil and air. In addition, they are completely different from other samples as they have some interfering compounds such as proteins, salts, peptides, and neutral components that may interfere with extraction and preparation of analytes in the sample. Therefore the use of new methods based on head space extraction leads to the elimination of interfering compounds.

The objective of current study was to develop a novel approach based on thermoelectric cooler device for the determination of 2,5-HD in urine samples. This device is reliable, fast and inexpensive technique to improve extraction efficiency and resolve the remaining problems with ordinary SPME fibers. This study was carried out in two phases. In the first one, the parameters for sampling and analysis of 2,5-HD by CF-HS-SPME sampler were evaluated and optimized. The sampler was then used for determination of 2,5-HD in a petrochemical complex.

\section{Experimental}

\subsection{Chemicals and Reagents}

All reagents $\left(\mathrm{Na}_{2} \mathrm{SO}_{4}, \mathrm{NaCl}\right.$ and $\left.\mathrm{KOH}\right)$ were of analytical grade. 2,5-HD and cyclohexanone (internal standard, IS) were supplied from Merck (Darmstadt, Germany). Stock solution $(1000 \mathrm{mg} / \mathrm{l}$ of $2,5-\mathrm{HD}$ and $5 \mathrm{mg} / \mathrm{l}$ of the IS) was obtained in purified water. Calibration standards for analysis were prepared in the range of $0.06-20 \mu \mathrm{g} / \mathrm{ml}$ in purified water.

\subsection{Equipment}

All samples were extracted from $20 \mathrm{ml}$ clear glass vial, sealed with silicone septum and an aluminum cap.
Seventy-five micrometers of carboxen/polydimethylsiloxane (CAR/PDMS) SPME fibers and manual holders were purchased from Supelco (Bellefonte, PA).

A gas chromatograph (Shimadzu GC-2010 system, Kyoto, Japan) equipped with a split/splitless injector and flame ionisation detector (FID) was used for analyses of 2,5-HD.

An alfa hs-810 model hot plate-stirrer (Tehran, Iran) was used for heating and stirring the samples during the SPME process. Temperature controller (Busan, South Korea), 220VAC/ $50 / 60 \mathrm{HZ}$ solenoid valve (0.25 89 bar/Class E, Mahar Fan Abzar Co., Tehran, Iran), soldering wires and other electronic components were purchased from electronic stores.

\subsection{Fabrication of the Cold Fiber SPME with Thermoelectric Cooler}

The thermoelectric cooler (TEC) was used to cool the SPME fiber. Detailed information on the design and structure of the thermoelectric cooler has been published elsewhere $[25,26]$. The temperature of fiber in TEC cooler was controlled by a fan and heat-dissipating silicon-oil based thermal grease. A copper plate was attached to the cold surface of the TEC to achieve more efficient cooling and improve the contact between the SPME needle and the cold side of TEC. The SPME fiber was placed in a groove in the middle of the copper plate. The temperature of fiber was measured by a thermocouple embedded in the copper rod.

\subsection{Optimization of Chromatographic Conditions}

The chromatographic column used in GC-FID was capillary RTX-WAX column $30 \mathrm{~m} \times 0.25 \mathrm{~mm}$ ID $\times 0.25 \mu \mathrm{m}$ (DF) (RESTEK, USA). GC was programmed at $313 \mathrm{~K}$ for $4 \mathrm{~min}$ and then ramped at $6 \mathrm{~K} / \mathrm{min}$ to $353 \mathrm{~K}$. FID detector was operated at $523 \mathrm{~K}$. The flow rate of carrier gas was optimized at $1.1 \mathrm{ml} / \mathrm{min}$.

\subsection{CF-HS-SPME Optimization}

The CAR/PDMS fibers are proven to have a higher affinity for extraction of volatile and semi-volatile compounds from the headspace of urine samples in previous studies $[11,12,15]$; therefore, they were chosen for extraction of 2,5-HD from the urine samples. They were conditioned for $2 \mathrm{~h}$ in the injection port of the $\mathrm{GC}$ at $573 \mathrm{~K}$.

The central composite design (CCD) was used to optimize based on a $2^{3}$ factorial design for optimized extraction temperature, time and sample volume.

The optimization of the SPME experimental parameters was carried out step by step in the laboratory 
to determine optimum condition and extraction efficiency of sample volume, extraction temperature extraction time, fiber temperature, and salt addition.

\subsection{Sample Preparation}

$5 \mathrm{ml}$ of human urine from non-exposed people with $5 \mu \mathrm{g} / \mathrm{ml}$ of internal standard were placed into a headspace vial containing a magnetic stirring bar $(1000 \mathrm{rpm})$ and a certain amount of $\mathrm{Na}_{2} \mathrm{SO}_{4}(25 \mathrm{w} / \mathrm{v} \%)$. The vial was capped tightly, placed in a water bath and heated at $338 \mathrm{~K}$ for $10 \mathrm{~min}$, then the cold fiber SPME needle (at $278 \mathrm{~K}$ ) pierced the vial septum in order to expose the fiber in the headspace of the solution for $17.5 \mathrm{~min}$. Finally, the needle was removed from the vial and inserted into the GC injection port $(503 \mathrm{~K})$ to desorb analyte for $2 \mathrm{~min}$. Fig. 1 shows the chromatogram for CF-HS-SPME-GC-ID of an urine sample spiked with 2,5-HD.

\subsection{Analytical Validation}

The chromatographic co-elution of 2,5-HD was evaluated by direct injection of 2,5-HD standard solutions into the GC. Standard solutions with six concentrations from 0.06 to $20 \mathrm{mg} / 1$ of $2,5-\mathrm{HD}$ and $5 \mathrm{mg} /$ of the IS were prepared in urine (blank samples) using the procedure of sample preparation. The calibration curves were arrived at by plotting $2,5-\mathrm{HD} / \mathrm{IS}$ peak-area ratios against the corres- ponding $2,5-\mathrm{HD} / \mathrm{IS}$ concentration ratios and validating the method. Under optimized conditions, the method was validated for linearity, limit of detection (LOD), limit of quantification (LOQ) and repeatability and extraction efficiency.

Each calibration level was analyzed in triplicate. Linear regression was calculated by the least mean square method. The LOD based on an estimated signal-to-noise ratio $(S / N)$ of 3 , and LOQ of the method were determined by calculating the concentration corresponding to a signalto-noise ratio of 10 for 2,5-HD. Repeatability of the method was examined for three consecutive days by analysis of urine samples spiked with $0.15,2.0$, and $10.0 \mu \mathrm{g} / \mathrm{ml}$ under the same conditions $(n=4$ per concentration per day, total $=36$ determinations) the samples were stored in 50-ml polyethylene disposable flasks at $253 \mathrm{~K}$.

Urine samples of 10 non-exposed and nonsmoking men were collected (blank samples) from healthy volunteers for optimization and validation of the method.

At the end of the workweek, post-shift urine samples were collected $(n=10)$ from workers exposed to $n$-hexane in a petrochemical complex. The urine samples were collected in 50-ml polyethylene flasks and stored at $253 \mathrm{~K}$ until analysis. The research was submitted and approved by the Committee of Ethics Hamadan University of Medical Sciences.

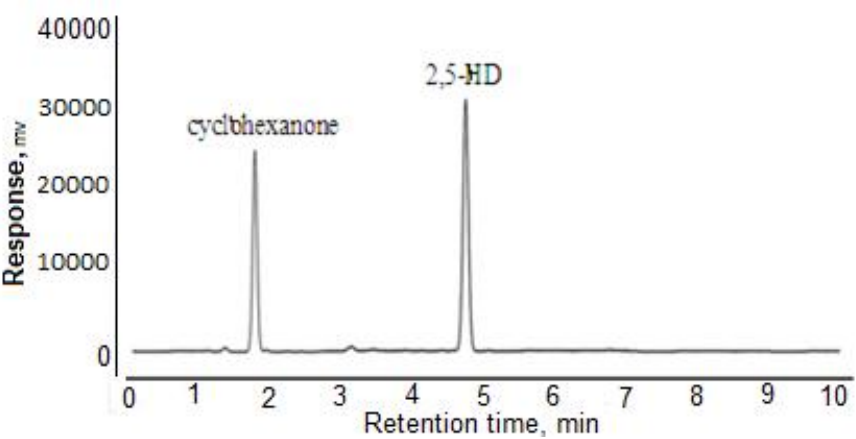

b)

a)

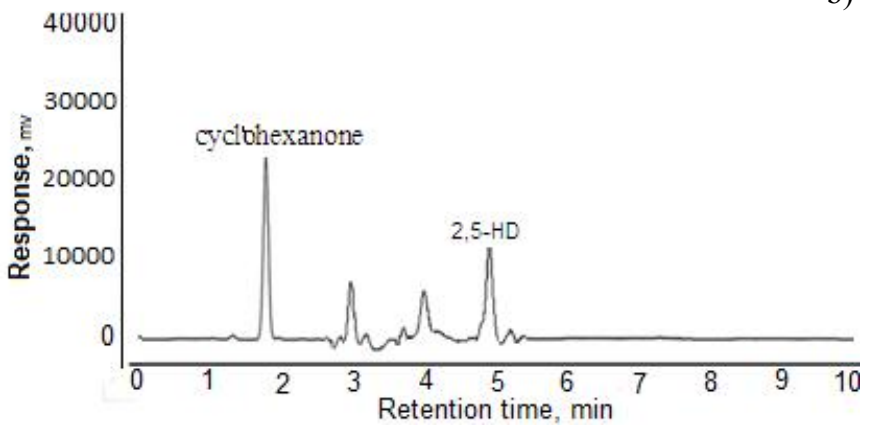

c)

Fig. 1. SPME-GC-FID chromatograms of a blank urine sample (a); a spiked urine sample containing $10 \mu \mathrm{g} / \mathrm{ml} 2,5-\mathrm{HD}$ and internal standard (b); a real sample of exposure worker containing internal standard (c) 


\section{Results and Discussion}

\subsection{GC Conditions}

Since 2,5-HD and cyclohexanone as internal standard are polar compounds, the RTX-WAX columns with polar properties were selected for this study. In order to separate analyte from cyclohexanone, a temperature program was optimized, and minimum peak tailing was observed. Fig. 1 presents chromatograms of blank and spiked urine samples. Using head space for extraction of 2,5 HD from urine samples caused elimination of interference from matrix and high boiling point compounds.

\subsection{Optimization of Extraction Temperature, Time and Sample Volume}

As the CF-HS-SPME is an equilibrium process between the fiber coating and vapor phase for extraction of 2,5-HD, the extraction temperature, extraction time and the sample volume are important parameters for the extraction of the analyte from the matrix. The phase equilibrium (sample/HS/fiber) in CF-HS-SPME also depends on the sample volume and the amount of the extraction is directly related to the concentration of analyte in matrix [27]. The extraction time and temperature in different volumes of sample for extraction were optimized with the CCD model.

In order to obtain the extraction temperature profile, the analytical procedure was performed for $20 \mathrm{~min}$ of preheating. Extraction temperatures of 323, 333, 343 and $353 \mathrm{~K}$ and the cold fiber placed in head space at 5, 10, 20 , and $30 \mathrm{~min}$ for absorption of the analyte were investigated. The sample volume was evaluated using $20 \mathrm{ml}$ vials and the volume of urine was increased from 5 to $15 \mathrm{ml}$ (headspace volume from 15 to $5 \mathrm{ml}$ ). A standard solution with the concentration of $10 \mathrm{mg} / \mathrm{l}$ for 2,5-HD was analyzed twice. Each data point is the average of three independent measurements.

The profiles show that the recovery of extraction process with cold fiber increases when the temperature of the sample is increased from 323 to $338 \mathrm{~K}$ (Fig. 2). The increase for $20 \mathrm{~min}$ has no effects on extraction efficiency. The highest extraction efficiency was observed at $338 \mathrm{~K}$ in 17.5 minutes for extraction of samples and $10 \mathrm{ml}$ of spiked water sample with $10 \mathrm{ml}$ of headspace volume and so was used for subsequent analysis. The CCD model showed that the amount of recovery was directly proportional to the temperature of extraction $338 \mathrm{~K}$ because the vapor pressure of 2,5-HD in the headspace increased with sample temperature, due to faster kinetics of desorption from the matrix. During the extraction process, when the fiber was cooled, the partition coefficient between the fiber and the headspace increased and more compounds were trapped in the fiber. The optimized time for extraction of 2,5-HD was around $17.5 \mathrm{~min}$, the rate of extraction efficiency $v s$. extraction time proved to be relatively constant after $17.5 \mathrm{~min}$; slight reduction in extraction efficiency at larger times is probably due to water vapor condensation on the fiber surface and rebound of the analyte molecules. Comparing to other studies, the time for extraction of VOC from different matrix is shorter than extraction time of 2,5-HD from urine, and low temperature for VOC extraction is needed [28].

The desorption time of placing fiber into the GC injector for the complete desorption of the trapped 2,5-HD from fiber of SPME was investigated within the range of $1-6 \mathrm{~min}$ at $503 \mathrm{~K}$. The results showed that 2 minutes are sufficient to remove analyte from the fiber and there was no carryover. Therefore, that value was considered the optimal desorption time for further studies.

To compare extraction time and temperature of CF-HS-SPME with HS-SPME, the extraction time and temperature of analyte with HS-SPME were optimized at different temperatures (293-363 K) and different times (20-70 min). The results are shown in Fig. 3.

The results of extraction temperature for CF-HSSPME were compared with HS-SPME. For HS-SPME the temperature profiles of the fiber and the head space of samples are both at the same temperature. A comparison of extraction time for CF-HS-SPME with HS-SPME (17.5 vs. $50 \mathrm{~min})$ showed that CF-HS-SPME needs less time for extraction of analyte.

\subsection{Salt Addition}

Salt addition can also influence the extraction yield due to the salting out effect, but this depends on the salt concentration and the type of the compound extracted. The effect of two types of salt (sodium chloride and sodium sulfate) with 5,10 and $20 \%(\mathrm{w} / \mathrm{v})$ concentrations were studied. The sodium sulfate has more effect on the extraction of analyte than sodium chloride. Slight increase in peak areas was observed with the increase in $\mathrm{Na}_{2} \mathrm{SO}_{4}$ concentration up to $20 \%$. With higher concentrations of $\mathrm{Na}_{2} \mathrm{SO}_{4}$ the extraction efficiency decreased.

\subsection{Fiber Temperature}

To understand this process, the effect of the sample matrix and fiber temperatures was investigated. This was carried out by analyzing 2,5-HD at optimum extraction time and temperature and various fiber temperatures. The fiber temperatures were studied within 278-298 K while the sample temperature was set at $338 \mathrm{~K}$. The results showed that the extraction increased when the coating temperature was decreased to $278 \mathrm{~K}$. 


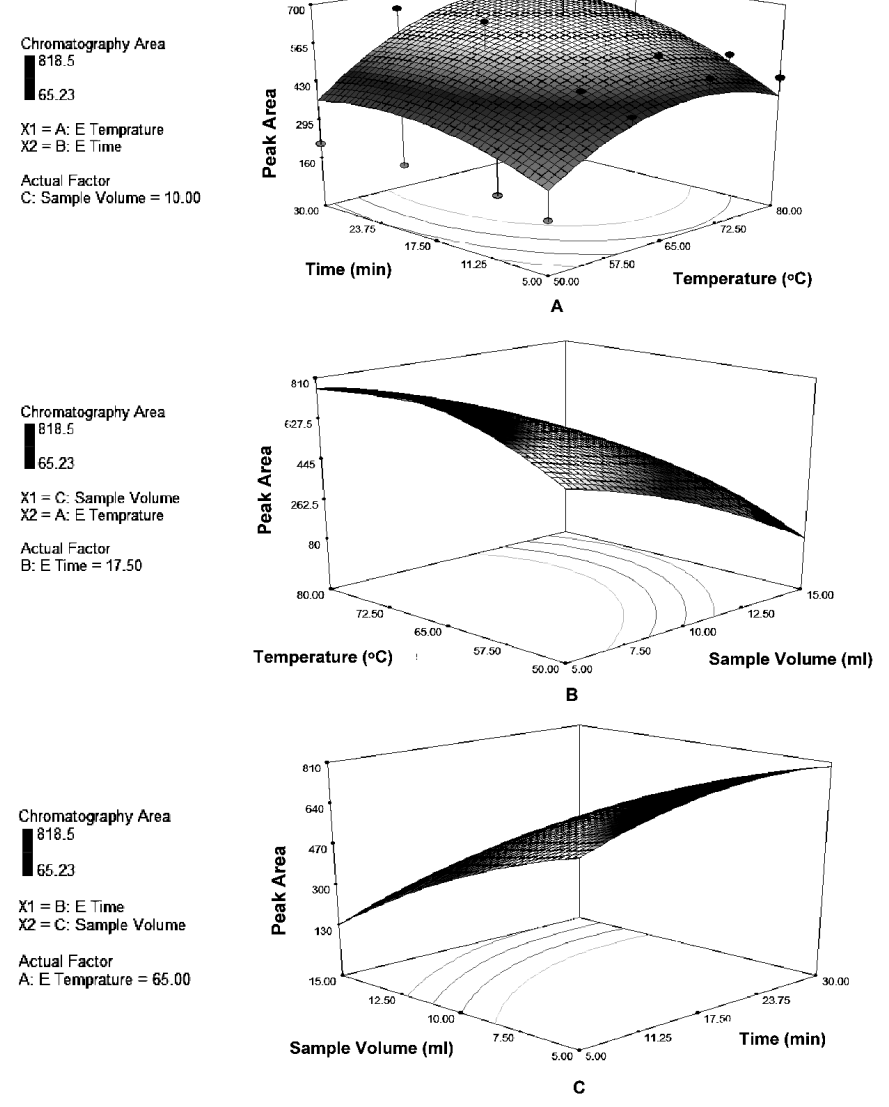

Fig. 2. Response surface obtained by CCD model for 2,5-HD: extraction time and temperature of extraction (A); sample volume and temperature of extraction (B); extraction time and sample volume $(\mathrm{C})$

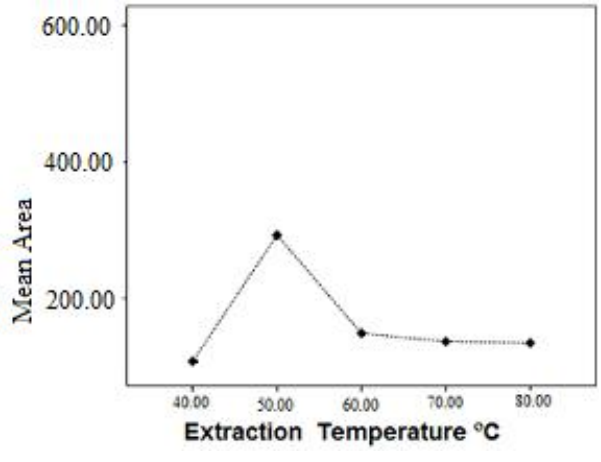

a)

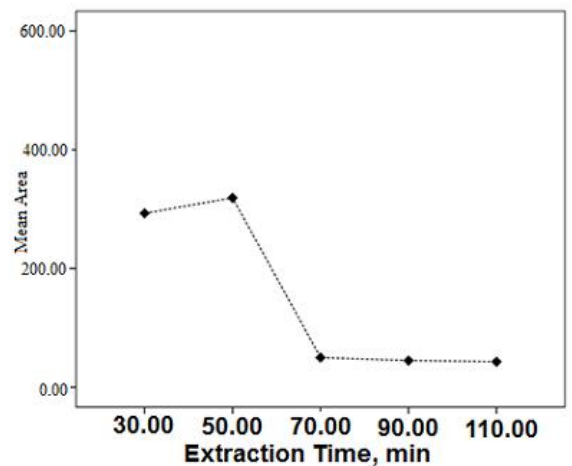

b)

Fig. 3. Effect of extraction temperature (a) and sorption time (b) on the extraction efficiency of HS-SPME

Comparison of proposed method with other reported methods for 2,5-HD determination

\begin{tabular}{|c|c|c|c|c|}
\hline LOD, $\mathrm{mg} / \mathrm{l}$ & LOQ & RSD, $\%$ & Analysis method & Reference \\
\hline 0.05 & - & $1.3-5.3$ & Liquid Chromatography/Mass Spectrometry & {$[8]$} \\
\hline 0.156 & - & $2.6-3.2$ & GC-electron capture and mass-selective detection & {$[29]$} \\
\hline 0.05 & 0.1 & - & GC-FID & {$[30]$} \\
\hline 0.05 & 0.1 & - & GC-FID & {$[31]$} \\
\hline 0.025 & 0.075 & $2.2-6.9$ & SPME-GC-FID & {$[15]$} \\
\hline 0.019 & 0.060 & $4.1-8.4$ & CF-SPME-GC-FID & Current study \\
\hline
\end{tabular}




\subsection{Validation of the Method}

The intra-day and inter-day relative standard deviations at $10 \mu \mathrm{g} / \mathrm{l}$ concentration level were within the acceptable ranges of $4.1-6.8$ and $4.8-8.4$, respectively. The method was found to be linear in the tested range $(0.06-20.0 \mathrm{mg} / \mathrm{l}(y=160.12 x+340.12)$ with correlation coefficients $R^{2}=0.995$. The LOD and LOQ of the method were 0.019 and $0.060 \mathrm{mg} / \mathrm{l}$, respectively. To evaluate sensitivity and precision of current method the LOD, intra-day and inter-day were compared with previous researches for determination of 2,5-HD in urine samples (Table). As can be seen, the LOD of current research is less than in previous studies and other results are comparable with the values reported for the other SPME devices.

The mean recovery of 2,5-HD was obtained at the concentrations of 5 and $20 \mu \mathrm{g} / \mathrm{ml}$ in $(n=5)$ the spiked urine samples of non-exposed people. The recovery was determined with ratio of area of spiked urine samples to calibration standard at the same concentration. The mean recovery for 5 and $20 \mu \mathrm{g} / \mathrm{ml}$ were $89-95$ and $91-96 \%$, respectively. As the SPME method is an exhaustive extraction method, therefore more than $90 \%$ of $2,5-\mathrm{HD}$ in the sample was adsorbed by fiber. In other words, the ratio of analyte on the extraction phase at equilibrium to the initial mass in the sample is between 0.9 and 1 [23].

The validated method was applied to the determination of 2,5-HD in urine from ten workers exposed to $n$-hexane in petrochemical complex. The biological exposure index [20] for 2,5-HD in urine, as recommended by the ACGIH, is $0.4 \mathrm{mg} / \mathrm{l}$. All workers' urinary $2,5-\mathrm{HD}$ were $0.08-0.29 \mathrm{mg} / \mathrm{l}$, which was within the acceptable range of exposure.

\section{Conclusions}

In this research, the CF-HS-SPME method based on thermoelectric cooling for the extraction 2,5-HD in urine samples was developed and analyzed by GC-FID. In the optimized conditions, the LOD was $0.019 \mu \mathrm{g} / \mathrm{l}$ with the linear range of $0.060-20.0 \mathrm{mg} / \mathrm{l}$. The chromatograms of analyte were clear with no interference to the analysis due to the matrix enabling the efficient and sensitive determination of the 2,5-HD in urine. The analytical method was successfully applied to the analysis of urinary samples of workers who had been exposed to $n$-hexane in a petrochemical complex. The results show that the method can separate 2,5-HD in urine from other compounds due to elimination of interferences from the urine by headspace sampling, selectivity of compounds by fiber, and polarity of column in chromatography. The thermoelectric cooling used in this research is a portable device that can be used in any laboratory. The method presented here is rapid, precise, sensitive and less labor intensive than conventional techniques such as LLE and the derivatization method.

\section{Acknowledgements}

The authors would like to thank Hamadan University of Medical Sciences for the financial support (Grant no. 940118143) that made this research possible.

\section{References}

[1] Morgan D., Jokinen M., Johnson C. et al.: Toxicol. Pathol. ,2016, 44, 763. https://doi.org/10.1177/0192623316638962 [2] Woehrling E., Zilz T., Coleman M.: Environ. Toxicol. Pharm., 2006, 22, 249. https://doi.org/10.1016/j.etap.2005.12.010

[3] Carelli V., Franceschini F., Venturi S., et al: Environ. Health. Perspect., 2007, 115, 113. https://doi.org/10.1289/ehp.9245 [4] American Conference of Governmental Industrial Hygienists. Threshold Limit Values for Chemical Substances and Physical Agents \& Biliological Exposure Indices. Cincinnati OH, 2015. [5] Van Engelen J., Kezic S., Haan W. et al.: J. Chromatogr. B, 1995, 667, 233. https://doi.org/10.1016/0378-4347(95)00029-I [6] Gori G., Bartolucci G., Sturaro A. et al.: J. Chromatogr. B, 1995, 673, 165. https://doi.org/10.1016/0378-4347(95)00257-X

[7] Colombini M., Carrai P., Fuoco R., Abete C.: J.Chromatogr. A, 1992, 592, 255. https://doi.org/10.1016/0021-9673(92)85092-8

[8] Andreoli R., Manini P., Mutti A. et al.: Rapid. Commun. Mass. Spectr., 1998, 12,1410. https://doi.org/10.1002/(SICI)10970231(19981015)12:19<1410::AID-RCM339>3.0.CO;2-M [9] Konidari C., Stalikas C., Karayannis M.: Anal. Chim. Acta, 2001, 442, 231. https://doi.org/10.1016/S0003-2670(01)01082-0 [10] Attari S., Bahrami A., Shahna F., Heidari M.: J. Anal. Chem., 2015, 70, 1192. https://doi.org/10.1134/S1061934815100032 [11] Attari S., Bahrami A., Shahna F., Heidari M.: J. Environ. Health Sci. Eng., 2014, 12, 1. https://doi.org/10.1186/s40201-0140123-5

[12] Zare Sakhvidi M., Bahrami A., Ghiasvand A. et al.: Anal. Lett., 2012, 45, 375. https://doi.org/10.1080/00032719.2011.644736 [13] Sakhvidi M., Bahrami A., Ghiasvand A. et al.: Environ. Monit. Assess., 2012, 184, 6483. https://doi.org/10.1007/s10661-011-2434-7 [14] Zeverdegani S., Bahrami A., Rismanchian M., Shahna F.: J. Sep. Sci., 2014, 37, 1850. https://doi.org/10.1002/jssc.201400262 [15] Heidari M., Bahrami A., Ghiasvand A. et al.: J. Sep. Sci., 2015, 38, 4225. https://doi.org/10.1002/jssc. 201500975

[16] Sakhvidi M., Bahrami A.,Ghiasvand A. et al.: Environ. Monit. Assess., 2013, 185, 4933. . https://doi.org/10.1007/s10661-0122914-4

[17] Jalali M., ZareSakhvidi M., Bahrami A. et al.: J. Res. Health Sci. 2016, 16, 153

[18] Zhang Z., Pawliszyn J.: Anal. Chem., 1995, 67, 34. https://doi.org/10.1021/ac00097a007

[19] Carasek E., Cudjoe E., Pawliszyn J.: J.Chromatogr. A, 2007, 5, 10. https://doi.org/10.1016/j.chroma.2006.10.092

[20] Carasek E., Pawliszyn J.: J. Agric. Food Chem., 2006, 54, 8688. https://doi.org/10.1021/jf0613942

[21] Chen Y., Begnaud F., Chaintreau A., Pawliszyn J.: J. Sep. Sci., 2007, 30, 1037. https://doi.org/10.1002/jssc.200600333

[22] Ghiasvand A., Pirdadeh-beiranvand M.: Anal. Chim. Acta, 2015, 900, 56. https://doi.org/10.1016/j.aca.2015.10.016 
[23] Ghiasvand A.: Flavour Fragr., 2007, 22, 377.

https://doi.org/10.1002/ffj.1809

[24] Tajik L., Bahrami A.,Ghiasvand A., Shahna F.: Chem Pap., 2017, 71, 1829.

[25] Haddadi S., Pawliszyn J.: J. Chromatogr. A, 2009, 1216, 2783. https://doi.org/10.1016/j.chroma.2008.09.005

[26] Tajik L., Bahrami A., Ghiasvand A., Ghorbani S.: Pol. J. Chem. Technol., 2017, 19, 9. https://doi.org/10.1515/pjct-2017-0041

[27] Pawliszyn J.: Solid Phase Microextraction: Theory and Practice. Wiley, New York 1997.

[28] Merib J., Nardini G., Bianchin J. et al.: J. Sep. Sci., 2013, 36, 2410. https://doi.org/10.1002/jssc.201201148

[29] Konidari C., Stalikas C., Karayannis M.: Anal. Chim. Acta, 2001, 442, 231. https://doi.org/10.1016/S0003-2670(01)01082-0

[30] Nolasco D., Gusmao A., Siqueira M.: Quim. Nova, 2007, 30, 805. https://doi.org/10.1590/S0100-40422007000400009

[31] Dos Santos C., Passarelli M., Nascimento E..: J. Chromatogr. B, 2002, 778, 237. https://doi.org/10.1016/S1570-0232(02)00036-3

\section{ТВЕРДОФАЗНА МІКРОЕКСТРАКЦІЯ \\ НА ОСНОВІ ХОЛОДНОГО ВОЛОКНА ДЛЯ АНАЛІЗУ 2,5 ГЕКСАНДІОНУ В СЕЧІ}

Анотація. 2,5-Гександіон (2,5-ГД), основний метаболіт н-гексану, був вилучений із зразків сечі з використанням твердофазної мікроекстракиії на основі холодного волокна (CF-HS-SPME) та проаналізований за допомогою газової хроматографії з детектором йонізачії полум'я (GC-FID). Важливі параметри для підвищення ефективності сорбиї волокна, включаючи об'єм зразка, час екстракиії та температуру, оптимізовані за допомогою ичентрального композиційного плану експерименту. Встановлено оптимальні умови, за яких визначено межу чутливості та відносні стандартні відхилення. Показано, щзо розроблений метод є швидким, чутливим та простішим у порівнянні із звичайними методами кількісного аналізу 2,5-ГД у зразках сечі.

Ключові слова: зразки сечі, 2,5-гександіон, холодне волокно, твердофазна мікроекстракція, н-гексан. 